Quiet and reserved, he was best known for his loyalty to friends and to business obligations, and for his ability to make decisions promptly and fairly, and to translate his decisions into immediate action.

Thoughtful of others and ready to lend assistance in a good cause, he was greatly beloved by all those who knew him. He was respected for his ability and judgment by his employees and associates, and will be greatly missed in the councils of Forest Industries, the North-Western Section of the Institute, and in his Company.

He is survived by his wife the former Margaret Mitchell, daughter Esther, and son Robert, all of Fort William.

\title{
G. H. PRINCE
}

Dr. Gilbert Hudson Prince, I.S.O., B.Sc., M.Sc., D.Sc., 64, New Brunswick's Deputy Minister of Lands and Mines for 28 years, and long prominent in the Province's forestry development, died at his home in Fredericton after a long illness.

Born at Hammond River, his chief interest was forestry and in this field he gained widespread recognition. His activities embraced aspects of provincial and national life, as well as such diverse duties as membership on the National Research Council, 1936-48 and as a commissioner of the Boy Scouts Association.

After his graduation in 1912, Dr. Prince went to British Columbia. There, he was employed by the B.C. forest service when it was organized under H. R. MacMillan, the first chief forester. From 1914-16 he was district forester for the Nelson district, then returning to New Brunswick to become director of the N.B. forest survey of the department of lands and mines. He rose to the office of chief forester in 1917 and to deputy minister of lands and mines in 1924. He held that office until about six months before his death, when he was appointed Executive Assistant to the Minister of Lands and Mines.

Dr. Prince was a member of the Canadian Institute of Forestry, and held offices both in that organization and the Canadian Forestry Association. He was a charter member of the New Brunswick Association of Registered Foresters, a director of the Maritime Lumber Bureau from its inception and a member of the Forest Insect Control Board.

In 1916 Dr. Prince was chief of a forest party which made a Crown land survey in New Brunswick. Later he was appointed provincial fire inspector for the Board of Railway Commissioners and a member of its New Brunswick advisory committee. 
Dr. Prince drafted this province's first forest service act and organized its forest service, establishing lookout towers at strategic points. The first of these went into service on Mount Hope, York County, in 1918.

In 1921 he drafted the Scalers Act and in 1932, as a member of the committee on lumber, attended the Imperial Economic Conference at Ottawa. He also was present for Dominion-provincial conferences in 1935, 1945-46. From 1941-46 he was chairman of the N.B. pulpwood advisory committee.

Dr. Prince was a member of the Eastern Canada lumber trade promotion committee and the national products control board of the province. $\mathrm{He}$ was on the examining board of registered foresters.. His other activities, too numerous to mention with justice, took him into work with the Canadian Legion, Trans-Canada Airlines, University of New Brunswick Alumni Association, the Frederiction Rotary Club and Christ Church Cathedral.

He is survived by his widow, formerly Minnie Lillian Dayton; two daughters, Mrs. W. W. Prest, Chalk River, Ont., and Mrs. Alvin Fulcher, Fredericton; three grandchildren; two brothers, George I., Hammond River, and Rev. Dr. S. H. Prince, professor of sociology at King's College, Halifax, and one sister, Miss M. Caroline Prince of Hammond River.

JOHN S. MOTTISHAW

John S. Mottishaw, 39, resident of Port Alberni for many years as forester for the former Bloedel, Stewart \& Welch operation which is now part of MacMillan \& Bloedel, Limited, died at Steilacoom, Washington.

Born at Duncan, British Columbia, he obtained his preliminary education in that city and afterwards graduated from the University of Washington.

He was well known as a sports enthusiast, particularly in basketball. As a younger man he played with Victoria Dominos, and in Alberni he coached his own team of juniors.

He was a member of the Rotary Club and active in community work in that district. In Washington he was engaged in tree farming.

His untimely death was a particular sorrow and loss to his many friends and associates, who saw in John Mottishaw one of the potentially outstanding men in his field.

Surviving are his wife, Marjory; three children, Gail, John and Jane; his parents, Mr. and Mrs. J. Mottishaw of Duncan; three brothers and two sisters, Henry, Ernest and Wesley, Mrs. Edna Eldren and Mrs. Irene Robertson; and a grandfather, J. West of Port Alberni, British Columbia. 